\title{
Cultivation Strategies of Professional English Ability of Cruise Service Program in Chinese Higher Vocational Schools
}

\author{
Qian Xi-lu \\ Hotel Management Department, Tourism College of Zhejiang, Hangzhou, China
}

Email address:

Ximilu05@163.com

\section{To cite this article:}

Qian Xi-lu. Cultivation Strategies of Professional English Ability of Cruise Service Program in Chinese Higher Vocational Schools. Science Journal of Education. Vol. 7, No. 6, 2019, pp. 121-126. doi: 10.11648/j.sjedu.20190706.12

Received: October 14, 2019; Accepted: November 6, 2019; Published: November 12, 2019

\begin{abstract}
China's cruise industry has developed rapidly. The major international cruise companies have entered the Chinese market, and the number of cruise tourists has also increased. However, the speed of China's cruise talent training is lagging behind the speed of industry development, and the quality of talents does not meet the requirements of enterprises. This paper analyzes the professional ability of the work position in the service department on board, and proposes six countermeasures to improve the English ability of cruise service-oriented students in China's higher vocational colleges: implementing the ability-based teaching philosophy, clarifying the professional English teaching objectives, and carrying out the use of ESP classroom teaching method, designing teaching plans and contents based on industry standards, clarifying the evaluation standards of the students' English language ability, and training the competent professional English teachers. For improving the English language ability of the students of the cruise service program, the paper concludes that the teachers need to establish a teaching philosophy based on competency, apply the ESP classroom teaching method, and to be trained with both English language teaching ability and cruise industry knowledge.
\end{abstract}

Keywords: Cultivation Strategies, English Teaching, Cruise Service Program

\section{Introduction}

According to global authoritative cruise agencies and organizations (PSA, CLIA, ECC), global cruise passengers will reach 25 million and 30 million passengers in 2015 and 2020, respectively [1]. The growth rate of the European market and the Asian market will be more obvious. 2012-2013 China Cruise Development Report demonstrated that the North American market is the base and the major region for the development of cruise tourism based on the comparison data of major cruise tourism markets. It has always occupied the most important share in the world cruise tourism market. Europe is the second-largest in the world after North America. In the cruise market, the cruise industry in the Asia-Pacific region has developed at a faster rate than the previous two regions. In particular, China and India are regarded as the main driving areas for the recovery of the Asian tourism market. The rapid expansion of the cruise industry in the Asian region has increased the demand for the cruise industry service talents in the region (including China), which has intensified the training gap for the cruise industry service talents. Since 2012, the cruise industry and related regions have paid more attention to the training and education of cruise professionals, and in practice, they have paid more attention to cooperation and exchanges with international companies and institutions. Both cruise companies and institutions are beginning to realize that talent is fundamental to the development of cruise emerging industries. Therefore, international cruise companies have begun to cooperate with Chinese institutions to establish their talent training centers. Tourism College of Zhejiang (TCZJ) is a higher vocational college in China that cooperates with international cruise companies earlier. The famous brand of Costa Crociere S.p.A., which belongs to Carnival International Cruises Co., Ltd., has established a training base with TCZJ in 2011, and in September of 2013, it officially began to recruit full-time students from the international cruise service program. Then, Tianjin Maritime Vocational College and the Royal Caribbean 
Cruises Co., Ltd. (RCL) established a cruise training base. This kind of training model combining industry with the colleges will surely bring vitality to the training of talents in China's cruise industry.

\section{The Specific Requirements of The Cruise Industry for Talents}

The rapid development of the cruise industry in the Chinese market has generated a large demand for various types of cruise professionals. In the process of international cruise companies entering the Chinese market, the recruitment ratio of Chinese cruise service personnel has been increased year by year. Besides, the development of the industry has created demand for high-quality talents such as guest relation service, guest service operation, cruise marketing planning, and cruise entertainment project management. Although there are already professional colleges related to cruise, the current training speed of domestic cruise talents is still far behind the growth rate of cruise liners operated by major cruise companies. At the same time, the quality of the cruise personnel cannot reach the requirements of the cruise company. According to the research on the demanded positions in the recruitment requirements of the Costa Cruises (see Table 1) and the feedback from the company on Chinese employees, it can be understood that the employees required by the cruise company are mainly concentrated in the service field, and do not need many management personnel. The cruise company believes that there is a shortage of professionals in the cruise service industry in China, especially Chinese employees have a poor foreign language ability, the low cross-cultural communication ability, and the insufficient flexibility in the event of an emergency.

Table 1. Analysis of the Cultivation of Language Ability of Professional English Courses on Cruise Ships.

\begin{tabular}{ll}
\hline Position & English language proficiency requirements \\
\hline Guest Service & Proficiency in English listening and speaking (can communicate with people and colleagues from different countries in \\
& English); polite language; professional English vocabulary at the guest service department \\
& Basic English listening and speaking ability (can communicate with passengers and colleagues from different countries, \\
understand the needs of passengers, and provide timely service and help); polite language; professional English vocabulary in & Housekeeping department \\
Housekeeping Service & Proficiency in English listening and speaking (can communicate with people and colleagues from different countries in \\
& English); polite language; professional vocabulary in food, catering and restaurant services \\
Catering Service & Proficiency in English listening and speaking (can communicate with people and colleagues from different countries in \\
& English); polite language; professional vocabulary in bar utensils and drinks \\
Bar Service & Skilled English listening and speaking skills (accessible to passengers and colleagues from different countries in English); \\
& polite language; professional English vocabulary in the tourism sector \\
Tour Service & Skilled English listening and speaking skills (accessible to passengers and colleagues from different countries in English); \\
Entertainment Service & polite language; entertainment sector vocabulary \\
(Adults and children) &
\end{tabular}

The strong English listening and speaking ability is a basic requirement for cruise service personnel [2]. In the process of designing the English proficiency training strategy for the students, the contents of the work positions and the English language proficiency listed in Table 1 are analyzed based on the requirements on the positions of the various departments of the international cruise company and the career development plan of the students.

According to the analysis of the work positions' capacity of the cruise crews, the biggest problem encountered by the cruise professionals in cultivating the talents of the cruise industry is the students' English language ability. Therefore, how to design and adjust the professional English teaching methods of the cruise and the English proficiency assessment standards to cultivate practitioners who meet the requirements of the international cruise company for English language proficiency are worthy of consideration and research.

\section{The Teaching Strategies for Improving the English Ability of the Students}

The rapid development of China's cruise industry will certainly play a guiding and feedback role in the English teaching process of the cruise service program. The industry guidance and its feedback are designed to help the students learn the relevant knowledge and the skills in a specific work position.

To improve the English ability of cruise students, the colleges have begun to try a variety of teaching strategies to improve the English ability of professional students, and can better meet the needs of enterprises in recent years. Li Yan and Sun Wei of Tianjin Maritime Vocational College, which cooperated with Royal Caribbean Cruises, conducted a survey on the results of cruise interviews, and proposed the development of professional evaluation standards, based on the common standards of European language teaching and assessment framework, for cruises, established test questions and promoted them to other institutions [3]. Mei Yingchun and Jiang Yunfeng of Nantong Shipping Vocational and Technical College, which cooperated with Sino-Singapore International Maritime Training Center (SNIMI), proposed to strengthen cultural introduction, situation construction and the classroom interactive activities based on the relevant theory related to pragmatic competence [4]; Xiao Jian proposed to provide students with an "immersive" English language learning environment [5]. Liu Shuang of Jinan Vocational College proposed to apply the CBLT model to the English teaching of cruise ships based on the ability-oriented teaching method (CBLT) [6]. Wan Xianmei of Jiangsu Maritime 
Vocational and Technical College analyzed the problems arising from the actual English teaching process and proposed to link practical English with industry English, create a modern curriculum system, arrange English teaching time reasonably, and better cultivate students' practical ability [7].

Based on the above-mentioned scholars' professional English teaching strategies and the concept of Australian Vocational Education (VET), the author believes that the professional English teaching of cruise service program needs the guidance and participation of the entire cruise industry and international large cruise companies. the school and the cruise company jointly develop a curriculum system and curriculum standards for the training of cruise service professionals.

\subsection{Implementing the Ability-based Teaching Philosophy}

Competency-Based Education (CBE), represented by the United States and Canada, was born after the Second World War. The core is to determine the ability goal from the needs of the professional positions. The concept is defined to develop the knowledge and skills that the students need to master the workplace and to apply the skills they have learned to new workplaces. The higher vocational education needs to possess three characteristics: industry-led, unified standards, and enterprise-concentric.

Therefore, an ability-based teaching philosophy is very suitable for today's Chinese higher vocational and technical education. The professional curriculum is designed to equip students with the work skills they need in a particular industry, and this competency standard is efficient to work performance.

The paper draws on the teaching and training concepts learned in the Australian Vocational Education and Training (VET) course, combined with the current teaching status of the professional English course of the cruise service program, and proposes that the students should learn eight skills in addition to the knowledge and skills of the profession: self-management ability, communication skills, teamwork skills, planning and organizational skills, self-learning skills, high-tech skills, problem-solving skills, innovation, and self-development capabilities.

\subsection{Clarifying the Target of Professional English Teaching}

Gao Suxia et al. proposed that the professional English teaching is different from basic English teaching, not only to enable students to master a wealth of professional theoretical knowledge but also to cultivate students' ability to understand the professional language and the practical application [8]. The professional English is a course that focuses on professional knowledge rather than the English language itself. The course should be based on teaching the English language with an explanation of the appropriate Chinese language. It must be made clear that the setup of the professional English course and its teaching are mainly aimed at mastering the professional knowledge and the latest trends in the field of development of the profession, rather than simply English language. Due to the high requirements of the cruise industry for the English language ability of employees, the professional English teaching of cruise service courses in the Chinese higher vocational colleges needs to adopt the bilingual teaching method based on English teaching. In the process of learning the professional English knowledge of cruises, the students need to use the English language to learn about cruise destinations, cruise products and all other professional knowledge related to cruise passenger services.

\subsection{Conducting the Use of ESP Classroom Teaching Method}

The purpose of the ESP class is to develop students' ability to use English in a real context. Therefore, both the textbook design and the classroom teaching should be authentic. The topic of authenticity, the real language background, and the real dialogue scene can make students feel immersive in the learning process, thus stimulating students' enthusiasm for learning. The authenticity of the teaching content can make the students transfer from passive absorption of knowledge to active learning, to achieve better teaching results.

The domestic scholars of China put forward the project-based teaching method according to the ESP classroom teaching theory when studying the English teaching problems of shipping professions [9], that is, practicing the tasks assigned by the teachers in the actual work process can improve the English level of the students. Some scholars have proposed the simulation work situations [10] to improve students' professional English reading level, and to use the situational teaching method [11] to improve students' listening and conversational levels. According to the study of English teaching methods for improving students' English proficiency at home and abroad, the design of situational tasks in cruise English teaching needs to rely on the real materials provided by the industry. The content of the teacher's lectures also needs to be updated as the industry develops. For the professional English course of the cruise service program, the teacher can extract the relevant English materials from the public webpage, such as teaching materials, related quizzes, useful teaching aids, and also can be obtained from the Cruise Industry Skills Council website (CLIA). The latest developments in the industry are the content of classroom teaching.

\subsection{Designing Teaching Plans and Contents Based on Industry Standards}

Table 2. Knowledge and content of professional English teaching.

\begin{tabular}{ll}
\hline Teaching key point & Teaching Contents \\
\hline $\begin{array}{l}\text { English language } \\
\text { knowledge }\end{array}$ & $\begin{array}{l}\text { English daily conversation; English service polite } \\
\text { language }\end{array}$ \\
$\begin{array}{l}\text { English vocabulary commonly used in cruises; } \\
\text { professional English vocabulary for all service } \\
\text { the cruise industry } \\
\text { positions on the cruise }\end{array}$ & $\begin{array}{l}\text { Learning and working } \\
\text { Learning and }\end{array}$ \\
learning attitude that meets industry requirements; \\
\hline
\end{tabular}

Based on the teaching content of Table 2, combined with the effective EPS teaching method, the professional English 
teaching model that is proposed by Zhang Anbin to cultivate students' job ability can be used [12]. In the actual teaching process, some of the teaching places are placed in the training center, and the real work tasks such as welcoming ceremony, a la carte service, wine service, cabin service, and children's entertainment center activities are used as carriers to make students integrate into the real working scene. The teachers can use various teaching methods including the lecture teaching method, the lecture teaching method, the case analysis method and the experiential teaching method according to the different teaching places, the different learning characteristics of students and the different teaching methods.

Table 3. Capacity-based professional English teaching design for cruise crew.

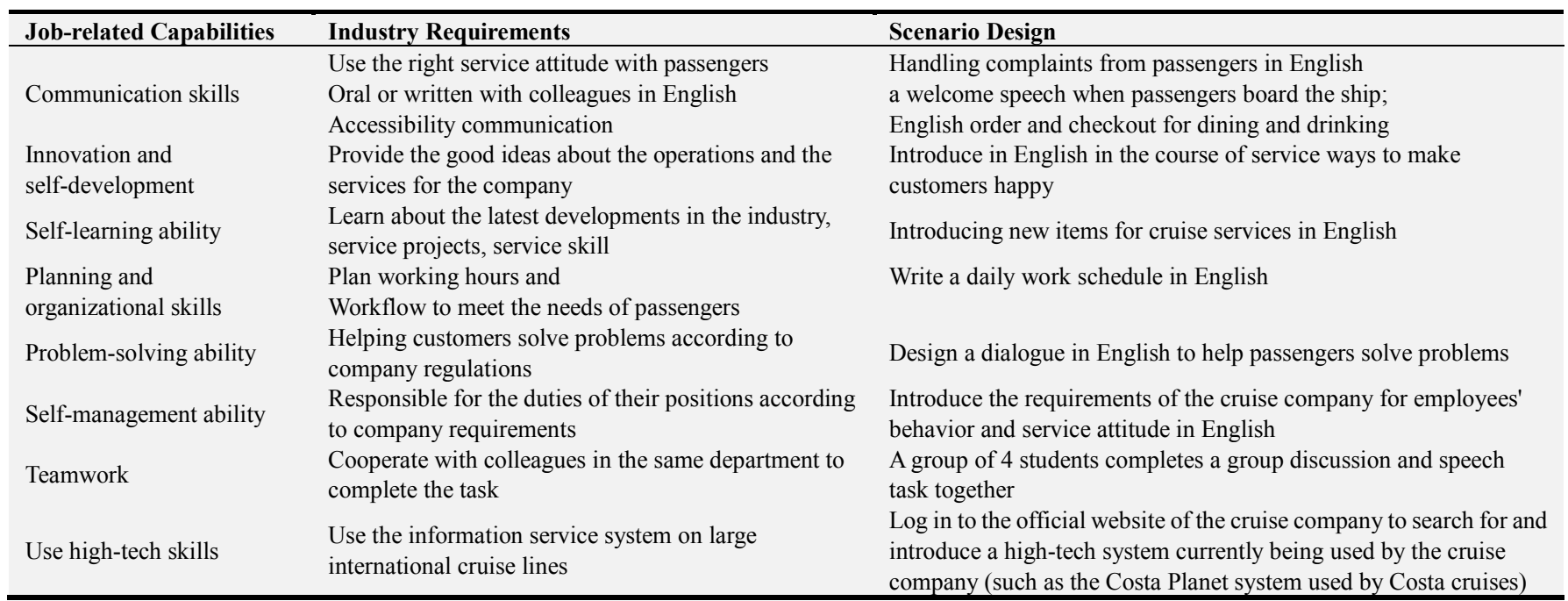

The entire teaching design needs to be completed through the guidance and review of the cruise industry or the cruise companies. The most effective way is to involve the large international cruise companies in the design process of professional course content and various teaching links and to develop the standards of the courses according to industry standards. The evaluation system will bring the students' good professional accomplishment and the skills about the different positions on board throughout the whole process of course teaching, and improve students' English application ability. Table 3 specifies the English-based instructional design of cruise-based professional English based on competency. The ability-based teaching is an important criterion for evaluating the quality of the students' learning and the quality of teachers' teaching based on their ability to work. The basic principle of assessment is whether the assessment method is effective, flexible, whether it is reliable (the evaluation criteria are consistent), and whether it conforms to the principle of fairness. Also, the assessment criteria need to be closely integrated with the assessment content, designed around the three main aspects of knowledge, ability, and attitude, and finally cultivate a service-oriented talent that meets the English language requirements of the cruise industry.

\subsection{Clarifying the Evaluation Criteria of Professional Students' English Language Ability}

The evaluation standard of employees' English proficiency and the company's English proficiency tests are adopted by Costa Cruises, combined with the school's assessment criteria to improve the English language ability of the professional students. According to the English language proficiency standards of Costa Cruises employees, table 4 shows the students' English language proficiency into six levels, as shown in Table 4.

Table 4. Evaluation level of English proficiency level of cruise students.

\begin{tabular}{ll}
\hline Level & Requirement \\
\hline Entry-level & Be able to use basic sentence patterns to achieve daily communication \\
A1 & Be able to make simple self-introductions and answer questions about your situation, such as where you live and your friends \\
& Be able to understand and fluently express information about yourself, such as personal and family information, shopping, local \\
& geography, and work experience \\
Basic Level & Be able to communicate easily and get information about each other \\
A2 & Be able to briefly describe the background of the scene, the environment of the scene and the events closely related to itself \\
& Be able to understand and express events related to work, school, leisure life, etc. \\
& medium level \\
Be able to handle situations such as using English in a target country \\
Bntermediate Level & Be able to communicate in English about personal interests \\
B1 & Be able to describe experiences, events, dreams, expectations, and explanations in English \\
Upper & Be able to understand the meaning of more complex articles, including technical discussion topics in special fields \\
\hline
\end{tabular}




\begin{tabular}{ll}
\hline Level & Requirement \\
\hline -intermediate Level & $\begin{array}{l}\text { Be able to express clear and detailed views on many topics, and can also comment on the topic from both advantages and } \\
\text { disadvantages }\end{array}$ \\
B2 & $\begin{array}{l}\text { Be able to understand a variety of long articles, and can understand the implications } \\
\text { Be able to communicate fluently and without the need for excessive expression assistance skills to express personal opinions. }\end{array}$ \\
& Be able to use language expressions flexibly and effectively with social, academic, and professional perspectives \\
Advanced Level & Be able to articulate clearly, rigorously and comprehensively on complex topics, while strictly using the sentence patterns, \\
C1 & conjunctions and tight structures of the regulations \\
& Be able to summarize the information from different heard or seen, and reorganize the language for debate \\
Professional Level & Be able to express their opinions naturally and fluently and accurately, and to distinguish subtle differences in content in complex \\
C2 & situations
\end{tabular}

\subsection{Training Competent Professional English Teachers}

Because of the differences between professional English courses and college English courses, professional English teachers are also different from ordinary English teachers. $\mathrm{Wu}$ Wei pointed out that due to the unclear qualification standards of professional English teachers, teachers who are born in English major lack professional knowledge and it is difficult to deepen the teaching of professional English. Other teachers who graduated from the profession or the industry are familiar with professional knowledge but English language knowledge [13]. The foundation is not deep enough, and the level of pronunciation, intonation, vocabulary and English teaching methods can not reach the level of English teachers, which limits and affects the improvement of students' professional English level and ability [14]. Most of the professional English teachers in the current institutions have been transformed from English teachers, which has resulted in a lack of professional knowledge. For professional English teachers in cruise ships, in addition to a solid English language skills, they also need their cruise expertise and effective teaching skills. This requires the professional English teachers to also need to return to the industry regularly and personally participate in the social practice of the enterprise projects [15]. The teachers are required to understand the cruise industry and its corporate culture as much as possible to ensure that their values are consistent with the corporate culture and the corporate values of the cruise industry. As the cruise industry grows and renews, the teachers need to be able to design and update their handouts so that their abilities are matched to the changing requirements of cruise companies.

\section{Conclusion}

The school's teachers are trying to use different teaching methods to improve students' English proficiency to meet the standards of the cruise industry. However, these methods are still in usage. Therefore, the cultivation of English language ability is the cornerstone of the cruise profession in Chinese higher vocational colleges. To achieve this training goal, we conclude several strategic paths to improve the English levels of the students of the cruise service program in Chinese higher vocational schools.

\subsection{Establishing a Teaching Philosophy Based on Competency}

To meet the requirements of the English language ability and workability of the employees of the cruise company is the teaching objectives of the cruise service program at the school. The employees' training content of the cruise company is the main curriculum structure. The foreign teachers of the industry are the main group of the teachers. And the English textbooks prepared by the company and the school together are the professional course materials. For the course examination method, the Train the Trainer - TTT Course is the teaching method for the Chinese professional teachers to achieve higher student satisfaction and faster improvement of students' various aspects.

\subsection{Applying the ESP Classroom Teaching Method}

The English language course is taught by Chinese teachers and the foreign teachers together. The main content is mainly about vocabulary and basic professional knowledge. The English-language (ESP) classroom teaching method is used to design the teaching materials closest to the working environment to cultivate the students' English language ability in the real context. The English course assessment method adopts the evaluation standard of the staff's English ability by the cruise company and the company's English proficiency test bank. The students' English language ability is divided into 6 grades, and the teaching content is designed in combination with the school's assessment criteria.

\subsection{Training a Faculty with Both English Language Teaching Ability and Cruise Industry Knowledge}

The professional teachers need to improve their teaching level by one-on-one lectures and the regular seminars with the industry teachers or the industry part-time teachers. At the same time, the teachers could enrich the content of the lectures to highlight the professional characteristics closely integrated with the industry. And then a cooperative teacher training model which integrates with the industry teachers could be established.

\section{Fund Project}

A specific subject of research of the Professional Leadership Training Program of "Thirteenth Five-Year" 
Zhejiang Provincial Higher Education Discipline, Zhejiang Higher Education Bureau (2017, No. 68).

\section{References}

[1] Yu Shicheng. 2012-2013 China Cruise Development Report [M]. Shanghai Pujiang Education Press. 2013: 2.

[2] Zhao Ling. Research on the Training Mode of Cruise Tourism Talents in Colleges and Universities [J]. Journal of Maritime Education Research, 2009. 2: 57-60.

[3] Li Yan, Sun Wei, Research on the Standardization of Professional English Speaking Assessment for Higher Vocational Cruises under the Background of Combination of Production and Education-Taking Tianjin Maritime Vocational College as an Example [J]. English Teachers, 2017, No. 19: 36-39.

[4] Mei Yingchun, Jiang Yunfeng, Research on the Pragmatic Competence Improvement of International Cruise Service Management Students Based on Relevance Theory [J]. Journal of Nantong Shipping Vocational College, Vol. 14 No. 3 Sep. 2015: 100-103.

[5] Xiao Jian, Practical Research on the Training Mode of English Compound Talents in Higher Vocational Cruises [J]. Journal of Maritime Education Research, 2015. 2: 63-67.

[6] Liu Shuang, Research on the Cultivation of Students' Language Ability in English Courses of Higher Vocational Cruises under CBLT Mode [J]. Journal of Jinan Vocational College, Oct. 2018 No. 5 (Serial No. 130): 17-18.

[7] Wan Xianmei, Talking about the Effective Connection between Practical English and Industry English Teaching in Higher Vocational Colleges [J]. Taxation, 2017, 32: 168-169.
[8] Gao Suxia, Yan Caiyun, Mao Yuhong. Strengthening professional English teaching to improve students' comprehensive ability [J]. Journal of Hetian Teachers College, Vol. 28, No. 6, 2009 (7): 247.

[9] Shi Min. Problems and Solutions of English Teaching in International Shipping Majors in Higher Vocational Colleges [J]. Journal of Maritime Education Research, 2014. 1: 101-102.

[10] Zhang Lijing. Application of Maritime English Reading Teaching Model in Simulated Work Situation [J]. Journal of Maritime Education Research, 2014. 2: 94-96.

[11] Wang Lijun, Zhuo Yongqiang, Wang Sisi. Maritime English Listening and Conversational Scenario Teaching Based on Ship Maneuvering Simulator [J]. Journal of Maritime Education Research, 2014. 1: 91-93.

[12] Zhang Anbin, A preliminary study on the reform of professional English teaching in higher vocational aircrew based on job demand [J]. Journal of Changsha Aeronautical Vocational and Technical College, Vol. 12, No. 1, 2012 (3): 16-20.

[13] Wu Wei, How to Develop Professional English Teaching in Higher Vocational Undergraduate Colleges [J]. Journal of Xingtai Vocational and Technical College, Vol. 26, No. 2, 2009 (4): 7-8.

[14] Zeng Jianping, Zeng Xiang, Research on Bilingual Teaching Materials [J]. Journal of Nanchang Institute of Aeronautical Engineering (Social Science Edition), Vol. 8 No. 1, 2006 (1): $87-90$

[15] Zheng Lijun, Australian Vocational Education Teacher Enterprise Practice: Background, Current Situation and Enlightenment [J]. Vocational and Technical Education, No. 27, 2014. 9. 20: 41 . 